\title{
Measuring Parental Involvement in Dual-Earner Qatari Families
}

\author{
Noora Lari $\mathbb{D}^{1} \cdot$ Noor Al-Emadi ${ }^{2}$
}

Accepted: 17 November 2021 / Published online: 11 December 2021

(c) The Author(s) 2021

\begin{abstract}
Parental involvement in dual-earner families is a subject that has been widely studied in the literature in Western contexts. Less attention, however, has been allocated to the challenges that dual-earner families encounter in raising children in Arab Gulf states. This paper study aims to address the following questions: To what extent are dual-earner families involved in their children's lives? What are the gender differences in parental involvement? This paper employed the 2017 survey data of working Qatari males and females to measure their parental involvement and engagement in family time and childcare. The results highlighted parental factors, work characteristics and social supports as key factors determining the degree of parental involvement. The results also showed the gender differences in parental involvement scores, which comprise several factors, including work demands and time spent with children. Taken together, our findings provide insights allowing suggestions for mechanisms that could generate foundational parental welfare policies for dual-earner families in Qatar and the wider Arab Gulf Region as a whole. Further contributions to this research domain could include studies encompassing a wider scope of geographical locations within the Arab Gulf states using robust experimental investigations.
\end{abstract}

Keywords Childcare $\cdot$ Dual-earner $\cdot$ Parenting $\cdot$ Qatar $\cdot$ Family Welfare

\section{Highlights}

- Work demands and time spent with children are associated with a greater potential of parental involvement scores.

- Compared with working mothers, fathers are less likely to spend time on childcare, indicating gender differences in parental involvement.

- Adequate social supports and labor policies should be formulated and implemented by the state to increase the level of parental involvement in dual-earner families.

Over the past two decades, immense social changes have been witnessed within the work-family contexts with the rise in the number of dual-earner families in the Arab Gulf region, resulting in work-family conflicts and influencing levels of parental involvement due to familial obligations and work responsibilities. Qatar is a small Arabian country with a high per capita income due to its oil resources and the diversification of its economy; these elements have boosted

Noora Lari

n.lari@qu.edu.qa

1 Manager of Policy Department, Social and Economic Survey Research Institute (SESRI), Qatar University, P.O. Box 2713, Doha, Qatar

2 Social and Economic Survey Research Institute (SESRI), Qatar University, P.O. Box 2713, Doha, Qatar production efficiency, thereby providing more support to the public and private sectors and involving more citizens in the workforce (Chamlou \& Karshenas, 2016). The Qatari government has adopted a number of initiatives prioritizing strategies for incorporating men and women into the workforce; as well as social welfare policies that aim to strengthen the Qatari family (e.g., National Development Strategy, 2018-2022). However, these family-friendly labor law provisions are limited, as they lack flexibility in working hours and provide inadequate paid paternity leave and childcare facilities.

The present paper expands on earlier studies by examining the gender differences in parental involvement among dual-earner Qatari families and investigating parents' attitudes toward state-directed welfare initiatives in Qatar. To accomplish these goals, the paper employs data from a national survey on family structure constructs and child-parent relationships and applies regression analysis 
approaches. In the following sections, we present the context of the Qatar labor market and the patterns of parental involvement. Thereafter, we describe our methods, data, and empirical strategy. Finally, we discuss the findings and draw some policy implications and conclusions.

\section{The Context of Qatar: Gender Ideologies and Welfare Regime}

Qatar represents a unique research setting for exploring parental involvement in the Arab Gulf (Lee, 2021), with its sense of cultural heritage and identity based on Islamic religious, and where gender role ideologies continue to shape social behavior and family values (Lee, 2021). The traditional family role model distinguishes the parents as the primary providers for the family, with the mother staying at home and serving as the primary caregiver and homemaker and the father as the breadwinner or primary financial provider. Fathers tend to be authoritative, decisive figures, are the key decision-makers in the home and family, and provide stability, safety, and security from infancy (Shafaie et al., 2014). A study in Qatar showed that mothers usually take care of children and are in charge of tasks like feeding and clothing; meanwhile, fathers tend to be responsible for financial support, security, entertainment, and transportation (Nasser (2016)). Likewise, in a study conducted in the United Arab Emirates, parents perceived themselves to be involved in their children's lives, yet most tended toward traditional family roles (Stocker \& Ali, 2014).

Qatar society has been rapidly changing as a result of its tremendous economic transformation, resulting in higher costs of living, as well as greatly influenced traditions, cultural values, and family structures and relations. The family structure is moving toward nuclear families, and tremendous strides have been made toward gender equality, women empowerment, and family welfare (Salem \& Yount, 2019). According to Al-Ammari and Romanowski (2016), there have been immense changes in the role of the husband and wife, increasing the number of women in the workplace, increasing the freedom of the children, and increasing the role of women in contributing to family finances. A statistical report presented that Qatari women are catching up with men in terms of their academic achievements and are more likely to be working in the labor market (Ministry of Development Planning \& Statistics, 2018). In fact, Al-Attiyah and Nasser (2013) indicated that Qatari women, on average, are more educated than their male counterparts. In 2017, Qatari females aged 15 and above had an economic participation rate of $36.7 \%$, sustaining them throughout their productive years, compared with $68.2 \%$ for Qatari males (Ministry of Development Planning and Statistics, 2018).
Consequently, the conception of the male patriarchy and breadwinner family model have been changing to the dualearner family model in conservative societies. A survey conducted on the economic underpinnings of women joining the workforce found that it is no longer feasible for men to be the sole breadwinners (Goldscheider et al., 2015). The study included interviews with a certain population of women, $45 \%$ of whom had pursued post-primary education. Half of them stated that they were working to support their husbands, fathers, or male providers due to the rising costs of living while still attending to their family responsibilities.

For dual-earner families, childbearing roles have increased the pressure on parents (Kilshaw, 2020), particularly on working mothers as they are expected to participate in paid work and to take care of their families simultaneously. This indicates that a care gap may exist because of workload pressures, leading families to seek help in childcare from their extended family members to help mothers balance their lives and preserve their good health and emotional well-being. A substantial number of Qatar families provide extensive alternatives to the children. Particularity, dual-earner families have hired household domestic help (Al-Ammari \& Romanowski, 2016) in order to manage childcare in the family and attain work-family balance. The rising standard of living has changed the functions and structure of the family with the family dependency on outsourced domestic help, such as nannies and babysitters (maids/servants), for childcare practices. Domestic maids have a key role in the management of Qatari households because they enable women to help with work at home and to adjust their responsibilities for work and leisure time instead of carrying out the tasks by themselves.

Furthermore, studies have found that receiving social support from extended family members or domestic help and institutions like childcare contribute to the level of parental involvement (Cochran \& Walker, 2005). For instance, McConnell et al., (2011) found that higher levels of parental social support were associated with lower levels of parenting stress. This suggests that social support has a direct effect on parent-child relations by creating informal "learning opportunities" and development outcomes for children (Ferreira et al., 2018). The government of Qatar has initiated welfare autocracy and policies to allow work-family reconciliation, enacting provisions related to child well-being, legal solutions, livelihood support, civil society solutions and child support. A study carried out by James-Hawkins, Qutteina, and Yount (2016) on Qatari welfare policies and their implications for Qatari women asserted that there have been three significant developments, including the incorporation of women into the workforce rather than viewing them only as mothers and home workers. 
Nevertheless, labor laws vary between the public and private sectors in the Qatar labor market. Currently, Qatari men and women are concentrated in the public sector, with $80.1 \%$ of women and $81.7 \%$ of men employed there. Interestingly, however, $84.6 \%$ of Qatari males were economically active in the Qatari private sector compared with $37.1 \%$ of Qatari females in 2017 (Ministry of Development Planning and Statistics, 2018). These differences between the two sectors may result from the fact that the public sector offers better work-family balance policies than the private sector. According to the Human Resources Law of 2016, which applies to the public sector, women can have 60 days of paid maternity leave, while the Labor Law of 2004 states that women can only apply for 50 days of paid maternity leave in the private sector. In the public sector, women are permitted two nursing hours for a period of two years compared with one nursing hour for a period of two years in the private sector. Given the foregoing, Al-Balam and Raza (2009) suggested that organizations should extend the current policies through offering leave credits, childcare support, flexible working hours (Mehdizadeh, 2015), government benefits, caregiving arrangements, parental ability training and fatherhood support.

\section{Parental Involvement among Dual-Earner Families}

Parental involvement Parental involvement was conceptualized in an early work by Kotila et al. (2013) as 'engagement, responsibility, and accessibility' (p. 795). They referred to engagement as positive activities that improve child development, for example, reading or playing with children. Activity-associated basic childcare was not considered to be an element of engagement. Meanwhile, responsibility was considered as the activities parents undertake to meet their children's needs, for example, arranging childcare. Accessibility pertains to the availability of parents when not indirectly or directly caring for the children (Lamb et al., 1987). It is multi-dimensional, determining the psychological investment in and importance of family to an individual; this involvement includes a set of beliefs and practices implemented to help develop children's lives, such as forms of supervision, home discussions, and school communication and participation (Ihmeideh, 2014).

Several studies have found moderate levels of paternal involvement (Benner et al., 2016; Betawi et al., 2014; Saraff \& Srivastava, 2010). Research has indicated the importance of co-parenting support, as paternal involvement in play prevents child behavior problems and improves youngsters' social skills (Jia et al., 2012). In the Arab context, a Jordanian study found that participants felt that both parents were responsible for their children's kindergarten-based activities. An awareness of the importance of paternal involvement in a child's early years has influenced fathers' practices regarding home-based activities (Betawi et al., 2014).

Several studies have identified numerous factors influencing parental involvement in terms of their interaction and availability; these factors include parental characteristics, such as gender, education level, and occupation (Cabrera et al., 2014; Castillo et al., 2011), and children's characteristics, including age and gender (Chaplin et al., 2005; Verhoeven et al. 2011). Studies have indicated that the parent's gender, age, educational level, and number of working hours contribute to the level of his/her parental involvement (Bradley \& Corwyn, 2002; Gracia, 2015). The number of parents' working hours affect the time they spend with their children on both routine and interactive activities. Bianchi et al. (2012) claimed that childbearing responsibilities and parenting role are associated with mothers, who are perceived as the primary caregivers more than fathers because of societal expectations and the biological role of mothers (Barnett \& Baruch, 1987; Beitel \& Parke, 1998; Bonney et al., 1999).

Parents with traditional gender role beliefs are more likely to practice parenting given the provision of breadwinning in the construction of the fathering identity and mothers' engagement with housework and childbearing responsibilities while fathers take on less responsibilities in childcare and involvement (Crouter et al., 1987; Hoffman, 1989; Jacobs \& Kelley, 2006). Working mothers tend to increase the time they spend in housework and childcare, unlike fathers. Job involvement and job-spouse conflict were positively related for individuals who ranked high in spouse involvement and unrelated for those who ranked low (Frone and Rice, 1987, p. 45). "The direction of work interference with family vs. family interference with work and the specific form of flexibility (flextime vs. flexplace; use vs. availability) make a difference in effects found" (Allen et al., 2012, p. 345). Men report similar levels of work-family conflicts as women in the family, with family interfering with work and work interfering with family (Shockley et al., 2017).

Employment influences the time spent with children because of the patterns of reconciliation of work demands and childcare in dual-earner households (e.g., BraungartRieker et al., 1999; Crouter et al., 1987; Crouter, 2006). The inclusion of parents' work hours and the pressure of time use are some of the main areas identified as being influential on dual-earner families, with the employment of a range of different strategies in order to cope with household work and childcare (Hyman et al., 2005). Adisa et al. (2016) pointed out that these disputes affect the individuals' levels of enjoyment at work while affecting their mental and 
physical conditions. Parents whose children remained at home faced several conflicts; for example, they found it difficult to concentrate at work due to concerns about their children's welfare.

McBride et al. (2002) found a relationship between child characteristics and the amount of involvement of parents in childrearing activities. Other studies have found contradictory findings between the level of parental involvement and child characteristics, such as age and gender of the child (Chaplin et al., 2005; Lam et al., 2012; Verhoeven et al. (2011)). Parents often treat their sons and daughters differently (Flouri, 2005; McKinney \& Renk, 2008), as fathers spend more time with their sons than with their daughters (Lamb, 2000). The findings also showed that parents tend to spend less time with children as they grow older (Lam et al., 2012; Phares et al., 2009; Verhoeven et al. (2011)).

\section{Theoretical Framework: Parenting, Work, and Family}

Scholars have applied various theories to multiple aspects of parental involvement in dual-earner families and workfamily relations (e.g., Green \& Piel, 2015), yet there have been a dearth of research in the Arab Gulf contexts to understand the conditions under which parents spend time with their children during daily interactions. Based on the theoretical arguments on parenting, work and family are created in a context arising from "accepted ways of thinking" (Collin, 2006, p. 296) about economic and social conditions, and not in a vacuum (e.g., Planalp \& BraungartRieker, 2016). The sociocultural theory (Vygotsky, 1980) stressed the relationship between the physical and social environments and individuals since cultural and social forces influence learning and development, especially through interactions with family members. Parental involvement has also been considered from the perspective of Piaget's cognitive development theory ((2001) [1981]) in which he emphasized the importance of the constructive role of all experiences with family members. For instance, he argued that parental involvement activities, including practicing interactive work, give opportunities to children to meaningfully interact with their parents, enabling the children to construct knowledge in physical and social environments during these activities (Bailey et al., 2004).

This study employed Lamb et al.'s (1987) conceptualization of parental involvement in terms of interaction, availability, and responsibility from the perspective of dual-earner families to examine the differential associations between the amount of time parents spend with their children and the parents' characteristics their its consequences for positive development. Our model examines parental involvement at the micro-level by theorizing the influence of parental factors (e.g., gender, education, occupation) and work characteristics (e.g., work type, work hours...) in predicting their interaction and availability, to measure the degree of time spent on parenting. The following hypotheses were formulated. First, for parental factors, we expected the parents' gender (Hypothesis 1) and educational level (Hypothesis 2); for work characteristics, we expected occupation (Hypothesis 3), and social support (i.e. institutional benefits and childcare arrangement) (Hypothesis 4) to be stronger predictors of the level of parental involvement. The following sections describe the methodology and procedures used to measure this framework.

\section{Procedures and Methodology}

\section{Sample Selection}

The data were collected using a national survey in 2017 . The sample was selected using stratified random sampling, and the samples within each stratum were then selected using simple random sampling. The sampling design was started by dividing the frame into the seven administrative municipalities in Qatar. Each municipality contained a number of zones, and each zone was divided into several blocks. In this survey, we ordered housing units in each zone by geographic location in order to attain an equally distributed sampling of housing units in different areas. In the sampling frame, all housing units in Qatar were listed with information about the housing address and information to identify whether the residents in the housing units were Qatari citizens.

A systematic sampling approach was then conducted to create a valid probability sample. Only one member (at least 18 years old) from the household was selected to participate in the study. All adult members in the household had the same chance of being sampled. The proportions of the adjusted weights on certain characteristics were consistent with their corresponding population. Participation was anonymous. All of the participants signed informed consent forms and provided information about the study and its objective.

The sample comprised 807 Qatari workers, both males and females, employed in public and private sectors. For this paper, The target population included 503 Qatari fathers and mothers who each lived with a biological child who was aged between 1 and 17 years and came from different families (i.e., the participants were not part of the same family). Table 1 shows the baseline characteristics of the participants. The average age was 43.1 years. There were 288 male respondents $(57.3 \%)$ with children and 215 female respondents with children (42.7\%). Almost $44.9 \%$ of the participants reported having completed a bachelor's degree or some form of higher education. Around $90 \%$ of the 
Table 1 Profiles of the study respondents with children $(N=503)$

\begin{tabular}{|c|c|}
\hline Variables & $N(\%)$ \\
\hline Age (Mean, SD) (in Years) ${ }^{\mathrm{a}}$ & $43.1(9.6 \%)$ \\
\hline \multicolumn{2}{|l|}{ Age category (in Years) ${ }^{\mathrm{a}}$} \\
\hline$>50$ & $110(22 \%)$ \\
\hline$>40-50$ & $174(35 \%)$ \\
\hline$>30-40$ & $174(35 \%)$ \\
\hline $18-30$ & $40(8 \%)$ \\
\hline \multicolumn{2}{|l|}{ Gender of respondent } \\
\hline Male & $288(57.3 \%)$ \\
\hline Female & $215(42.7 \%)$ \\
\hline \multicolumn{2}{|l|}{ Educational level } \\
\hline Less than secondary school & $90(17.9 \%)$ \\
\hline Secondary school/post-secondary/diploma & $187(37.2 \%)$ \\
\hline Higher education (university) & $226(44.9 \%)$ \\
\hline \multicolumn{2}{|l|}{ Work type } \\
\hline Government organization & $449(90 \%)$ \\
\hline Private organization & $22(4 \%)$ \\
\hline A public non-profit organization & $1(1 \%)$ \\
\hline Self-employed & $14(2 \%)$ \\
\hline \multicolumn{2}{|l|}{ Work schedule } \\
\hline Full-Time & $477(96 \%)$ \\
\hline Part-Time & $24(4 \%)$ \\
\hline \multicolumn{2}{|l|}{ Spouses' work schedule } \\
\hline Full-time & $250(54 \%)$ \\
\hline Part-time & $83(5 \%)$ \\
\hline Other & $170(41 \%)$ \\
\hline \multicolumn{2}{|l|}{ Monthly income (in US Dollars) ${ }^{b}$} \\
\hline Less than $\$ 11,000$ & $202(41.7)$ \\
\hline$\$ 11,000$ or More & $282(58.3)$ \\
\hline \multicolumn{2}{|l|}{ Children ages by categories } \\
\hline Infant $(0-1$ yrs $)$ & $124(7 \%)$ \\
\hline Toddler (2-4 yrs) & $323(19 \%)$ \\
\hline Pre-adolescents (5-12 yrs) & $879(50 \%)$ \\
\hline Adolescents (13-17 yrs) & $415(24 \%)$ \\
\hline
\end{tabular}

${ }^{a}$ Data not available for 5 subjects

${ }^{\mathrm{b}}$ Data not available for 19 subjects

participants had five children or less under the age of 18 years categorized as follows: $50 \%$ of the children were preadolescents aged between 5 and 12 years, $24 \%$ of the children were between the age of 13 and 17 years, and only $7 \%$ were infants. In terms of work characteristics, the participants worked mostly five days a week full-time outside the home for pay, with $54 \%$ having spouses working fulltime outside the home for pay. Up to $90 \%$ of the respondents worked in government organizations (i.e., ministries), $43 \%$ of whom were in the public administration and defense sector. Most of the participants (58.3\%) reported earning more than US\$11,000 per month.

\section{Variables and Their Measurements}

The survey scales was administered using the local language (i.e., Arabic), and was guided by several questions related to the dimensions of parental involvement in terms of interaction and availability. Each parent completed a self-report of the following item to measure the work hours and family time. The respondents were also asked to specify the amount of time that they typically spend with their spouses and their children using a three-point Likert scale labelled as follows: "too much" (scored as 1), "enough" (scored as 2), and "not enough" (scored as 3). Furthermore, the respondents were asked to specify how often during the prior three months had they not had enough time to do things with their children because of their jobs. In this rating, they used a four-point Likert scale labelled as follows: (1) always, (2) often, (3) seldom, and (4) never. Parents were also asked to determine the extent to which they agree or disagree with various statements regarding their level of parental involvement.

Test-retest reliability, construct validity, and predictive validity were utilized to measure the internal consistency of the self-reported data (Reimers et al., 2012). For statistical analysis, the means with their corresponding standard deviations (SDs) were calculated for continuous variables and proportions were calculated for categorical variables. For the primary outcome of "parental involvement," we performed a bivariate analysis as the initial step. Potential variables (parent's gender, education, age, and working status) were entered into the association model, and their corresponding $p$-values were recorded. For the multivariable regression analysis, we considered all variables for which the $p$-value was less than 0.25 (Hosmer et al., 2013). Sampling weight adjustment was performed using svyset command, and a $p$-value $<0.05$ was considered statistically significant.

\section{Results: Predictors of Parental Involvement}

The analyses showed the main factors shaping parental involvement, namely, parental factors (e.g., gender and education), work characteristics (e.g., occupation, work type and work hours), engagement characteristics (e.g., the amount of time spent with children and the spouse's level of involvement with children as the primary caregiver), and social supports and benefits (e.g., institutional factors, such as parental leave, flexible work hours, and childcare arraignments done by family members such as grandparents and household workers). These factors were identified to be significant predictors of parental involvement in terms of parents' interactions and availabilities. Hypothesis 1 postulated parents' gender to be a stronger predictor of the level of parental involvement. Based on the results, differential relations exist in the time spent by young children with their 
employed mothers and fathers, which leads to the acceptance of H1. Regarding Hypothesis 2, the perception that the parents' levels of education influence the level of parental involvement could not be verified and the results did not support hypotheses, in contrast to what was expected. Hypothesis 3, which tested whether the parents' occupation status (working or not) influences the level of parental involvement, it was found to have a positive effect, thereby supporting the hypothesis. Finally, Hypothesis 4, as the construct of social support (i.e. institutional benefits and childcare arrangement), was verified to be a strong predictor of the level of parental involvement.

Table 2 illustrates the results of the multivariable linear regression model constructed for this study. The results suggest that there are no underlying relationships between educational attainment and parental involvement (OR -0.33 ; $95 \%$ CI: $-0.84,0.17)$. In terms of the gender differentials reported, parent's gender (i.e., mother or father) was significantly associated with the respondent spouse's parental involvement.

Both fathers and mothers believe that they are highly involved in their children's lives, with rates of 53\% and 50\%, respectively. The mothers' beliefs regarding their spouses' levels of involvement with children were low, with $47 \%$ of the mothers reporting that their spouses were highly involved, $35 \%$ sufficiently involved, and $15 \%$ insufficiently involved. In contrast to their wives, the majority of the fathers believed that their spouses were highly involved in their children's lives $(75 \%)$ and that mothers take more responsibility in childcare. The analysis in Table 2 also shows a positive association between the spouse's working status and parental involvement. Those with full- or part-time occupations (i.e., those respondents whose spouses work in public and private organizations) were more likely to spend less time with their

Table 2 Regression model of factors determining parental involvement

\begin{tabular}{|c|c|c|}
\hline Variables & Standardized $B(95 \%$ CI $)$ & $P$ value \\
\hline \multicolumn{3}{|l|}{ Education } \\
\hline - Less than secondary school & Ref & \\
\hline - Secondary school/diploma & $-0.33(-0.84,0.17)$ & 0.193 \\
\hline University degree & $-0.03(-0.52,0.45)$ & 0.901 \\
\hline Gender & $0.05(0.02,0.09)$ & 0.004 \\
\hline \multicolumn{3}{|l|}{ Working status } \\
\hline - Not working & Ref & \\
\hline - Works fulltime/part time & $-0.50(-0.85,-0.14)$ & 0.007 \\
\hline \multicolumn{3}{|c|}{ Amount of time with children (self-perceived) } \\
\hline - Enough & Ref & \\
\hline - Not enough & $-0.42(-0.79,-0.04)$ & 0.030 \\
\hline \multicolumn{3}{|c|}{ Spouse's level of involvement with children } \\
\hline - Enough & Ref & \\
\hline - Not enough & $-0.89(-1.66,-0.12)$ & 0.023 \\
\hline
\end{tabular}

spouses and children than those whose spouses did not work outside the home (OR -0.50 ; $95 \%$ CI: $-0.85,-0.14$; Table 2). The amount of time that parents spent with their children has a greater potential to indicate parental involvement and interaction engagement scores with a $p$ value $<0.030^{*}$. The self-perceived spouse's level of involvement with children also has higher odds of explaining spouses' high parental involvement, with a $p$ value $<0.023 *$.

Moreover, the findings showed that the males were more satisfied $(60 \%)$ than the females $(40 \%)$ with regards to their working hours. However, almost $29 \%$ of the females, compared to only $7 \%$ of males, reported that they were not satisfied with their working hours. This dissatisfaction might result from married women's numerous family responsibilities, leading to difficulties in balancing family and work responsibilities. Most females and males lack flexible hours; they are not allowed to work part-time from home. However, when looking at the percentages of the respondents who replied, "Yes, I do this now," the males scored $8 \%$ higher than the females in terms of having flexible working hours. By contrast, working part-time from home was more common for the females than for the males. The results in Table 3 indicate that most fathers thought that their jobs rarely affect their time $(41 \%)$ for their children because of their jobs, indicating an adequate degree of involvement. Meanwhile, 29\% of the mothers felt that their jobs held no significant interference with their time (often $=28 \%$, seldom $=29 \%$ ). The results indicate that $57 \%$ of the males disagreed and $43 \%$ agreed with the statement that their job clashed with their desire to spend more time with their children. By comparison, 54\% of the females agreed with this statement, while $46 \%$ disagreed.

\section{Childcare Arrangement, Availability and Engagement}

The findings indicate that $56 \%$ of the males felt that they spend enough time with their children. By comparison,

Table 3 Work and Childcare Time

How often have the respondents not had enough time for their children

\begin{tabular}{llllll}
\hline & Always & Often & Seldom & Never & Total \\
\hline Fathers & $5 \%$ & $35 \%$ & $41 \%$ & $19 \%$ & $100 \%$ \\
Mothers & $18 \%$ & $28 \%$ & $29 \%$ & $25 \%$ & $100 \%$
\end{tabular}

The respondents' job clashes with their desire to spend time with their children

\begin{tabular}{lll}
\hline & Agree & Disagree \\
\hline Fathers & $43 \%$ & $57 \%$ \\
Mothers & $54 \%$ & $46 \%$ \\
\hline
\end{tabular}


$48 \%$ of the females reported that they do not spend enough time with their children. A total of $70 \%$ of the males felt that their spouses spend enough time with their families. While $51 \%$ of the females thought that their spouses spend enough time with their families, $45 \%$ had the opposite opinion. These results indicate that mothers are generally more involved and that they do not see the same levels of involvement and time spent with children perceived by fathers. Participants were also asked to report how often they spent time with their children in different activities and skills outside of school hours between both fathers and mothers including: playing, helping their children with their homework, worshipingrelated activities, watching TV and participating in family recreational/exercise and leisure activities. The findings indicated that leisure activities were generally highly spent with fathers than mothers.

\section{Social Supports and Institutional Benefits}

For an evaluation of parental involvement in dual-earner families, the participants were asked to report the amount of direct childcare done by the parents as opposed to that done by other family members, such as grandparents and household workers. For fathers, the most chosen option to take care of children was the participants' spouses (58\%), then nanny or maid in their home $(21 \%)$, then parent or parent-in-low in the respondents' home (12\%). Nevertheless, the mothers seemed to prefer different arrangements from the fathers', with $33 \%$ of the mothers depending on nannies or maids to take care of the children, 24\% depending on their parents or parents-in-low who live with them, and only $8 \%$ depending on their spouses for childcare. Correspondingly, the parents were requested to determine their level of satisfaction with the childcare arrangement they indicated. The majority of parents were satisfied with the level of care the other member has been provided (almost 95\%). Institutional factors include workplace policies and benefits that could be applied to ease the process of parenting for dual-earner families. Thus, the participants were given a list of statements including different policies and benefits to determine the level of importance of each statement in increasing their parental involvement and engagement with their children. For the statement on giving parental paid leave to mothers and fathers in order to care for their children, $45 \%$ of the mothers found it very important to have this type of leave while $40 \%$ of the fathers perceived this as somewhat important. Moreover, the mothers believed that having onsite breastfeeding rooms and onsite childcare facilities are very important $(46 \%$ and $58 \%$ ) compared with fathers (30\% and $29 \%)$. Finally, the importance of part-time job sharing or other reduced hours options was found to be more crucial for mothers $(51 \%)$ compared with fathers $(35 \%)$.

\section{Discussion}

This paper signals the ongoing transformations of gender discourse and family functioning at the micro-level within dual-earner families in Qatar. Considerably, it provides insights into the involvement predictor variables, including parental factors and work characteristics (e.g., gender, working status), childcare engagement (e.g., the amount of time spent with children as the primary caregiver), and social supports (e.g., institutional factors and childcare arrangement). Although it is not possible to determine direct associations with the present data, a relatively national representative sample was surveyed, where independent mothers and fathers self-reported their involvement in childcare and their perceptions of their spouses' involvement in childcare to generate an in-depth understanding of the family roles and type of parental involvement in childcare. Likewise, the results support the proposition that the parenting role is self-determined, indicating the quality of involvement that support much of the previous studies examining the structural (e.g., parents' time at work) elements that determine the percentage of time parents spend in childcare relative to their partners as opposed to the attitudinal determinants (e.g., beliefs about gender roles within the family context).

The traditional family roles that perceived men as breadwinners and women as caregivers have been reshaped and are moving toward sharing household duties and parenting roles. In patriarchal contexts, married women are considered fully responsible for household tasks, including cleaning, washing, and cooking, whereas the husband is considered responsible for working outside the home for wages. Yet, the employment rate for women in Qatar is higher than that in other countries such as Saudi Arabia (17\%), Oman (25\%), and Bahrain (30\%) (Golkowska, 2014). Notably, these results highlight the incorporation of mothers into the workforce during their childbearing years, yet they remain responsible for their children (Selwaness \& Krafft, 2021). There is little potential for developing equal contribution by men and women to childcare and a disproportionate share of time and energies in child rearing since men have failed to share the responsibility for housework and the care of children (Mackey, 1985).

Interestingly, when the respondents were asked to determine their own level of involvement with their children, the results indicated that the working mothers were generally more involved, met parental responsibilities, demonstrated better parenting interactions with 
their children, and that they do not see the same levels of self-perceived involvement from the fathers. Moreover, compared with the working mothers, the fathers were less likely to spend time with their young children, indicating gender differences in parental involvement scores in terms of interaction, engagement, accessibility, and percentage of time serving as primary caregivers for their children. At the same time, mothers, more than fathers, felt that they could not manage this involvement adequately due to difficulties in managing family and work responsibilities.

Furthermore, the mothers' self-report regarding their spouses' involvement in parenting and childcare demonstrated traditional societal expectations about parental roles that continue to pose a hurdle to fathers' involvement in childcare as the primary caregivers for their children. Consistent with our predictions, previous studies (Beitel \& Parke, 1998; Bonney et al., 1999) indicated that the more hours mothers worked outside the home, the more responsibility fathers took in childcare involvement and activities. Our results suggested that interaction and engagement in childcare activities (e.g., playing, watching TV, or participating in family recreational/ exercise and leisure activities) are generally spent more with fathers than with mothers, suggesting the amount of time and responsibility men accounted for in childcare. Yet, other childcare arrangements are expected to happen through a family member (e.g., parent or parent-in-law in the respondents' home) or a hired domestic help or babysitter to help take care of the children while the parents are at work, giving them a chance to engage in employment, which is in line with several studies (e.g., Al-Ammari \& Romanowski, 2016; Cochran \& Walker, 2005; McConnell et al., 2011).

Ultimately, when assessing the institutional factors influencing parental involvement, the findings revealed that married males were more satisfied with their working hours than married females. As one might expect, the more hours parents work outside the home, the less time they spend in childcare. There are several policies that constrain women's parental involvement, such as the lack of parental paid leaves, part-time, and remote work, as well as the absence of childcare facilities and onsite breastfeeding facilities at work (Assaad et al., 2020; Hayo \& Caris, 2013). These deficiencies make it difficult to spend the required amount of time with children and find the balance between work and family demands. Many studies have reported the positive impacts of paternity leave policies on fathers' involvement and engagement in their children's development (Tanaka \& Waldfogel, 2007; Petts \& Knoester, 2018). In the Qatari context, there is no clear law or statement related to paternity leave. The modern model expects the father to be a stable attachment, an early cognitive stimulator for children through interaction and engagement in a father-child relationship.

\section{Policy Implications: Promoting Parental Welfare Programs}

The interconnectivity between work and family, which draws upon gender roles and intergenerational support, is a binding factor in the future of dual employment. This relies on intergenerational support from both the State and within the family unit in order to support dual-employed households through welfare programs that determine the economic, physical, psychological, and social wellbeing of individuals (Bönke, 2008, Furstenberg, 2005, Albertini 2016). A study by Majamaa (2011) revealed that social risks were simultaneously developing with the decline of welfare state support for couples, including the lack of basic levels of social security (e.g., childcare allowance) and financial support. The State should formulate effective family-friendly policies to increase the duration and engagement of parents with their children (Assaad et al., 2020; Hayo \& Caris, 2013). Thus, existing welfare regimes must be amended to benefit parents as part of statedirected efforts, providing flexible avenues promoting work-life balance and time management, as well as arranging the adequate support and distribution of parenting duties between parents.

Several welfare benefits and services have been established to increase the likelihood of direct parental childcare. For instance, the child-support enforcement awards, as part of Wisconsin's Child Support Assurance Program, proved that such programs have a positive effect on the reception of child support and that fathers tend to cooperate in rearing their own children, thereby reducing dependency on mothers (Hill \& Hill, 1990). Consequently, establishing parental welfare programs in labor firms, providing on-site daycare centers or childcare support for working parents, flexible work schedules, schoolbased childcare facilities, would encourage parents to increase their level of involvement and engagement with their children, and would assist in attaining a better work-family balance. Additionally, policymakers could introduce reforms to national policies in terms of the length and duration of maternity leave, offer paid paternal leave options and subsidized childcare provision rates.

A deeper acceptance of the transformation from traditional gender roles to shared responsibilities is essential for work-family balance within dual-employed families (Primeau, 2000). Matias and Fontaine (2015) found that female coping mechanisms were more associated with work-family conflict and work-family enrichment than coping with their male companion. They highlighted the need to reduce the stigma of historical gender roles in work-family management. The study suggests that despite couple-based coping strategies being the most successful in managing dualincome households, women still bear most of the responsibility to carry out these tasks in order to make the dynamic work. However, this usually inhibits a mother's level of 
parental involvement and work performance (Said-Foqahaa \& Maziad, 2011). Particularly, mothers often report missing days at work, leaving work early, dealing with family issues during working hours, and spending unproductive time at work because of childcare issues (Hill \& Hill, 1990).

Under patriarchal societies, the amount of paternal investment are magnified by social expectations and gender roles. Thus, changes must be made in the social system to reshape public attitudes and social expectations, possibly contributing to the likelihood of increasing fathers' involvement in childcare by enhancing their motivations. This requires long-lasting revisions to labor law, making them compatible with child-rearing duties. There are several interventions underpinning parental roles that decrease mens' feelings of responsibility for the direct care of children and hinder the full equalization of childcare roles. As such, gender role expectations should be shifted for longterm benefits (Hill \& Hill, 1990). The inclusion of fathers in parenting can be facilitated via tools that promote legal codes and awareness of fatherhood-involvement benefits through educational curricula in coordination with national civil society organizations.

\section{Limitations and Directions for Future Research}

Although the paper contributed to expanding the limited body of scholarly work about the much-needed multidimensional measures of parental involvement and father engagement in wage-family orientations for child wellbeing in the region, several conceptual and methodological caveats to the study have been reflected in the measures of parenting interventions. Despite preliminary evidence of the reliability and validity of the cross-sectional survey design, the scales with measures of related parental involvement constructs were self-reported by the participants. This method was subject to the bias involved in the delivery of parenting interventions and did not enable an investigation of the relationship between the measurements. Another methodological limitation was that the number of children in the families and the target children's ages varied. The different age ranges sampled had different developmental needs, which may have placed different demands on parenting.

The present study raised crucial research implications for future studies, paving the way for parental involvement with comparative analyses between Qatar and the wider Arab Gulf states since there are some significant commonalities that make these models comparable. Research studies would benefit from assessing the aspects of parental engagement alongside disparate parenting strategies, using evaluation tools to gather information, and monitoring how these relate to child outcomes of a parenting intervention to detect changes in parental involvement and engagement in the long term with the aim of enhancing the interventions for child well-being. Although not a focus of our study, future research could investigate the role of fatherhood involvement and of domestic helpers' and babysitters' personal levels of involvement in the intervention outcomes, along with specific measurements of the involvement demands (engagement, responsibility, accessibility, and birth order differences).

Future extensions of parental involvement positions can shed light on the interlinked questions related to a specific child age group (e.g., infants, toddlers, children under five, preschool children, and adolescents). Additionally, it should consider a comprehensive research design to include a robust experimental investigation and employ longitudinal linkages in parental differentials. There is a need to employ observational measures on parenting interventions with two-parent dual earners (i.e., mothers and fathers) with specific age ranges and to carry out in-depth interviews along with focus groups to produce qualitative data. This should include follow-up assessments for a comprehensive policy program, thus allowing causality between the interventions and outcomes to be determined in order to test for generalizability of the results.

\section{Conclusions}

Cultural dimensions shape the public's perception of family roles and the household division of labor in professional settings, guided by patriarchal views and societal norms. This paper's analytical model adds to the literature by providing evidence for parental differentials as apparent in dual-earner families at the micro-level, which pose some main hurdles in the full involvement of parents in childcare. The model revealed that paternal childcare time is influenced by individual-level parental and work factors (e.g., gender, occupation, and work characteristics), aside from social support factors (i.e., institutional benefits and childcare arrangement) in the job market. These suggest that gender differences have been predominately apparent in Qatari dual-earner families. The study limitations highlighted above could account for the lack of significant intervention effects on parental involvement knowledge. Future research can investigate the role of parental motivations with varying demographics in the Arab Gulf region.

Acknowledgements Authors acknowledge that the the project was funded by Doha International Family Institute (DIFI) and the data was collected by the Social and Economic Survey Research Institute (SESRI) at Qatar University.

Funding Open Access funding provided by the Qatar National Library. 


\section{Compliance with Ethical Standards}

Conflict of Interest The authors declare no competing interests.

Ethical Approval All procedures performed in studies involving human participants were in accordance with the ethical standards of the institutional and/or national research committee and with the 1964 Helsinki declaration and its later amendments or comparable ethical standards. The research protocol was approved by the institutional review board of the Qatar University, QU-IRB 597EA/16, under which the Social and Economic Research Institute (SESRI) operates.

Informed Consent We are pleased to invite you to participate in a 30 minutes' survey questionnaire to find out the impacts of workfamily conflicts in Qatar. Your participation in this study is purely voluntary. If you decide to participate, you can refuse to participate in any part of this study, or refuse to answer any or all of the questions, and you can withdraw from the study at any time. If you want to know more details about what was mentioned above or about information not mentioned here, please do not hesitate to request it from the researchers mentioned at the top of the page.

Publisher's note Springer Nature remains neutral with regard to jurisdictional claims in published maps and institutional affiliations.

Open Access This article is licensed under a Creative Commons Attribution 4.0 International License, which permits use, sharing, adaptation, distribution and reproduction in any medium or format, as long as you give appropriate credit to the original author(s) and the source, provide a link to the Creative Commons license, and indicate if changes were made. The images or other third party material in this article are included in the article's Creative Commons license, unless indicated otherwise in a credit line to the material. If material is not included in the article's Creative Commons license and your intended use is not permitted by statutory regulation or exceeds the permitted use, you will need to obtain permission directly from the copyright holder. To view a copy of this license, visit http://creativecommons. org/licenses/by/4.0/.

\section{References}

Al-Ammari, B., \& Romanowski, M. H. (2016). The Impact of Globalisation on Society and Culture in Qatar. Pertanika Journal of Social Sciences \& Humanities, 24(4). http://hdl.handle.net/10576/18011.

Al-Attiyah, A., \& Nasser, R. (2013). Gender and age differences in life satisfaction within a sex-segregated society: sampling youth in Qatar. International Journal of Adolescence and Youth, 21(1), 84-95. https://doi.org/10.1080/02673843.2013.808158.

Al-Balam, N. M., \& Raza, S. A. (2009). Impact of family responsibilities on career success among employees working in the semigovernment sector in the state of Qatar. International Journal of Arab Culture, Management and Sustainable Development, 1(2), 208-223. https://doi.org/10.1504/IJACMSD.2009.030663.

Assaad, R., Hendy, R., Lassassi, M., \& Yassin, S. (2020). Explaining the MENA paradox: rising educational attainment yet stagnant female labor force participation. Demographic Research, 43(28), 817-850. https://ssrn.com/abstract $=3153349$.

Adisa, T., Osabutey, E., \& Gbadamosi, G. (2016). Understanding the causes and consequences of work-family conflict. Employee Relations, 38(5), 770-788. https://doi.org/10.1108/ER-11-20150211.
Albertini, M. (2016). Ageing and family solidarity in europe patterns and driving factors of intergenerational support. Policy Research Working Paper, 7678, 2-12. https://ssrn.com/abstract=2781299.

Allen, T. D., Johnson, R. C., Kiburz, K. M., \& Shockley, K. M. (2012). Work-family Conflict and flexible work arrangements: deconstructing flexibility. Personnel psychology, 66(2), 345-376. https://doi.org/10.1111/peps.12012.

Braungart-Rieker, J., Courtney, S., \& Garwood, M. M. (1999). Mother-and father-infant attachment: families in context. Journal of Family Psychology, 13(4), 535 https://doi.org/10.1037/ 0893-3200.13.4.535.

Bailey, L. B., Silvern, S. B., Brabham, E., \& Ross, M. (2004). The effects of interactive reading homework and parent involvement on children's inference responses. Early Childhood Education Journal, 32(3), 173-178. https://doi.org/10.1023/B:ECEJ. 0000048969.91442 .36 .

Benner, A., Boyle, A., \& Sadler, S. (2016). Parental involvement and adolescents' educational success: the roles of prior achievement and socioeconomic status. Journal of Youth and Adolescence, 45 (6), 1053-1064. https://doi.org/10.1007/s10964-016-0431-4.

Betawi, I. A., Abdel Jabbar, S. K., AL Jabery, M. A., Zaza, H. I., \& Al-Shboul, M. (2014). Father Involvement with Three-to-fouryear Olds at Home: Giving Fathers a Chance. Early Child Development and Care, 184(12), 1992-2003. https://doi.org/10. 1080/03004430.2014.903943.

Barnett, R. C., \& Baruch, G. K. (1987). Determinants of fathers' participation in family work. Journal of Marriage and the Family, 49, 29-40. https://doi.org/10.2307/352667.

Beitel, A., \& Parke, R. (1998). Parental involvement in infancy: the role of maternal and paternal attitudes. Journal of Family Psychology, 12, 268-288. https://doi.org/10.1037/0893-3200.12.2. 268.

Bönke, P. (2008). Are the poor socially integrated? the link between poverty and social support in different welfare regimes. Journal of European Social Policy, 18, 133-150. https://doi.org/10.1177/ 0958928707087590.

Bonney, J. F., Kelley, M. L., \& Levant, R. F. (1999). A model of fathers' behavioral involvement in child-care in dual-earner families. Journal of Family Psychology, 13, 401-415. https:// doi.org/10.1037/0893-3200.13.3.401.

Bianchi, S. M., Sayer, L. C., Milkie, M. A., \& Robinson, J. P. (2012). Housework: who did, does or will do it, and how much does it matter? Social forces, 91(1), 55-63. https://doi.org/10.1093/sf/ sos 120 .

Bradley, R. H., \& Corwyn, R. F. (2002). Socioeconomic status and child development. Annual Review of Psychology, 53, 371-399. https://doi.org/10.1146/annurev.psych.53.100901.135233.

Cabrera, N. J., Fitzgerald, H. E., Bradley, R. H., \& Roggman, L. (2014). The ecology of father-child relationships: an expanded model. Journal of Family Theory \& Review, 6(4), 336-354. https://doi.org/10.1111/jftr.12054.

Castillo, J., Welch, G., \& Sarver, C. (2011). Fathering: the relationship between fathers' residence, fathers' sociodemographic characteristics, and father involvement. Maternal and Child Health Journal, 15(8), 1342-1349. https://doi.org/10.1007/s10995-0100684-6.

Chaplin, T. M., Cole, P. M., \& Zahn-Waxler, C. (2005). Parental socialization of emotion expression: gender differences and relations to child adjustment. Emotion, 5(1), $80 \mathrm{https} / / /$ doi.org/10. 1037/1528-3542.5.1.80.

Cochran, M., \& Walker, S. (2005). Parenting and Personal Social Networks. In T. Luster \& L. Okagaki (Eds.), Parenting: An Ecological Perspective. Second Edition (pp. 235-273). Rougtledge. https://doi.org/10.4324/9781410613394.

Chamlou, N., \& Karshenas, M. (Eds.). (2016). Women, Work and Welfare in the Middle East and North Africa: The Role of Socio- 
demographics, Entrepreneurship and Public Policies. World Scientific. https://doi.org/10.1142/9781783267347_0001.

Collin, A. (2006). Conceptualising the Family-friendly Career: The Contribution of Career Theories and A Systems Approach. British Journal of Guidance \& Counselling, 34(3), 295-307. https://doi.org/10.1080/03069880600769225.

Crouter, A. C. (2006). Mothers and Fathers at Work: Implications for Families and Children. In: A. Clarke-Stewart \& J. Dunn (Eds.). Families count: Effects on Child and Adolescent Development (pp. 135-154). New York: Cambridge University Press. https:// doi.org/10.1017/CBO9780511616259.007.

Crouter, A. C., Perry-Jenkins, M., Huston, T., \& McHale, S. M. (1987). Processes underlying father involvement in dual-earner and single-earner families. Developmental Psychology, 23, 431-440. https://doi.org/10.1037/0012-1649.23.3.431.

Ferreira, T., Cadima, J., Matias, M., Vieira, J. M., Leal, T., Verschueren, K., \& Matos, P. M. (2018). Trajectories of parental engagement in early childhood among dual-earner families: effects on child self-control. Developmental Psychology, 54(4), $731 \mathrm{https} / / /$ doi.org/10.1037/dev0000458.

Frone, M. R., \& Rice, R. W. (1987). Work-family conflict: the effect of job and family involvement. Journal of Organizational Behavior, 8(1), 45-53.

Flouri, E. (2005). Fathering and Child Outcomes. John Wiley \& Sons. https://doi.org/10.1002/job.4030080106.

Furstenberg, F. F. (2005). Banking on families: how families generate and distribute social capital. Journal of Marriage and Family, 67, 809-821. https://doi.org/10.1111/j.1741-3737.2005.00177.x.

Gracia, P. (2015). Parent-child leisure activities and cultural capital in the united kingdom: the gendered effects of education and social class. Social Science Research, 52, 290-302. https://doi.org/10. 1016/j.ssresearch.2015.02.005.

Golkowska, K. U. (2014). Arab women in the gulf and the narrative of change: the case of Qatar. International Studies: Interdisciplinary Political and Cultural Journal (IS), 16(1), 51-64. https://doi.org/ 10.2478/ipcj-2014-0004.

Goldscheider, F., Bernhardt, E., \& Lappegård, T. (2015). The gender revolution: a framework for understanding changing family and demographic behavior. Population and Development Review, 41 (2), 207-239. https://doi.org/10.1111/j.1728-4457.2015.00045.x.

Green, M. G., \& Piel, J. A. (2015). Theories of Human Development: A Comparative Approach. Routledge, New York, USA: Psychology Press Book. https://doi.org/10.4324/9781315662466.

Hoffman, L. W. (1989). Effects of maternal employment in the twoparent family. American Psychologist, 44, 283-292. https://doi. org/10.1037/0003-066X.44.2.283.

Hill, E. M., \& Hill, M. A. (1990). Gender differences in childcare and work: an interdisciplinary perspective. Journal of Behavioral Economics, 19(1), 81-101. https://doi.org/10.1016/0090-5720 (90)90019-4.

Hayo, B., \& Caris, T. (2013). Female labour force participation in the MENA region: the role of identity. Review of Middle East Economics and Finance, 9(3), 271-292. https://doi.org/10.1515/ rmeef-2013-0021.

Hosmer Jr, D. W., Lemeshow, S., \& Sturdivant, R. X. (2013). Applied logistic regression (398). John Wiley \& Sons. https://doi.org/10. 1002/9781118548387.

Hyman, J., Scholarios, D., \& Baldry, C. (2005). Getting on or getting by? employee flexibility and coping strategies for home and work. Work, Employment and Society, 19(4), 705-725. https:// doi.org/10.1177/0950017005058055.

Ihmeideh, F. M. (2014). Giving fathers a voice: towards father involvement in early years settings. Early Child Development and Care, 184(7), 1048-1062. https://doi.org/10.1080/03004430. 2013.842562 .
James-Hawkins, L., Qutteina, Y., \& Yount, K. (2016). The patriarchal bargain in a context of rapid changes to normative gender roles: young arab women's role conflict in Qatar. Sex Roles, 77(3-4), 155-168. https://doi.org/10.1007/s11199-016-0708-9.

Jia, R., Kotila, L. E., \& Schoppe-Sullivan, S. J. (2012). Transactional relations between father involvement and preschoolers' socioemotional adjustment. Journal of Family Psychology, 26(6), 848 https://doi.org/10.1037/a0030245.

Jacobs, J. N. and Kelley, M. L. (2006). Predictors of Paternal Involvement in Childcare in Dual-Earner Families with Young Children. Psychology Faculty Publications. 65. https://doi.org/10. 3149/fth.0401.23.

Kilshaw, S. (2020). Pregnancy and Miscarriage in Qatar: Women, Reproduction and the State. London: Bloomsbury. https:// discovery.ucl.ac.uk/id/eprint/10096793/.

Kotila, L. E., Schoppe-Sullivan, S. J., \& Kamp Dush, C. M. (2013). Time in parenting activities in dual-earner families at the transition to parenthood. Family relations, 62(5), 795-807. https://doi. org/10.1111/fare.12037.

Lam, C. B., McHale, S. M., \& Crouter, A. C. (2012). Parent-child shared time from middle childhood to late adolescence: developmental course and adjustment correlates. Child Development, 83(6), 2089-2103. https://doi.org/10.1111/j.1467-8624.2012.01826.x.

Lamb, M. E., Pleck, J. H., Charnov, E. L., \& Levine, J. A. (1987). A Biosocial Perspective on Paternal Behavior and Involvement. In J. Lancaster, J. Altmann, A. Rossi, \& L. Sherrod (Eds.), Parenting Across the Lifespan: Biosocial Dimensions (pp. 111-142). New York: Aldine de Gruyter. https://core.ac.uk/download/pdf/ 151574365.pdf.

Lamb, M. E. (2000). The history of research on father involvement: an overview. Marriage \& Family Review, 29(2-3), 23-42. https:// doi.org/10.1300/J002v29n02_03.

Lee, S. S. (2021). A precarious balancing act: globalization, political legitimacy, and higher education expansion in Qatar and the UAE. Contemporary Arab Affairs, 14(1), 113-133. https://doi. org/10.1525/caa.2021.14.1.113.

Primeau, L. (2000). Divisions of household work routines and child care occupations in families. Journal of Occupational Science 7 (1), 19-28. https://doi.org/10.1080/14427591.2000.9686461.

Majamaa, K. (2011). Dismissed intergenerational support? new social risks and the economic welfare of young adults. Journal of Youth Studies, 14(6), 729-743. https://doi.org/10.1080/13676261.2011. 588942.

Matias, M., \& Fontaine, A. (2015). Coping with work and family: how do dual-earners interact? Scandinavian Journal of Psychology, 56 (2), 212-222. https://doi.org/10.1111/sjop.12195.

McConnell, D., Breitkreuz, R., \& Savage, A. (2011). From financial hardship to child difficulties: main and moderating effects of perceived social support. Child: care, health and development, 37(5), 679-691. https://doi.org/10.1111/j.1365-2214.2010. 01185.x.

McKinney, C., \& Renk, K. (2008). Differential parenting between mothers and fathers: implications for late adolescents. Journal of family Issues, 29(6), 806-827. https://doi.org/10.1177/0192513x07311222.

McBride, B. A., Schoppe, S. J., \& Rane, T. R. (2002). Child characteristics, parenting stress, and parental involvement: fathers versus mothers. Journal of marriage and family, 64(4), 998-1011. https://doi.org/10.1111/j.1741-3737.2002.00998.x.

Mehdizadeh, N. (2015). Measures to Promote Work-family Reconciliation in the MENA region: Parental Leave, Childcare and Food Practices. DIFI Family Research and Proceedings, 2013. https:// doi.org/10.5339/difi.2013.arabfamily.3.

Mackey, W.C. (1985). Fathering Behuviors: The Dynamics of the Man-Child Bond. New York: Plenum. https://rd.springer.com/ book/10.1007/978-1-4613-2425-6. 
Ministry of Development Planning and Statistics. (2018). Woman and Man in the State of Qatar: A Statistical Portrait 2018. Retrieved from https://www.psa.gov.qa/en/statistics/.

Nasser, R. (2016). Women perceived practices of mothering in a socially changing Qatari. Society. The Social Sciences, 11, 1248-1256. https://doi.org/10.3923/sscience.2016.1248.1256.

Petts, R. J., \& Knoester, C. (2018). Paternity leave-taking and father engagement. Journal of Marriage and Family, 80(5), 1144-1162. https://doi.org/10.1111/jomf.12494.

Piaget, J. (2001). The Language and Thought of the Child. London: Routledge. https://www.routledge.com/The-Language-and-Thoughtof-the-Child/Piaget/p/book/9780415267502.

Planalp, E. M., \& Braungart-Rieker, J. M. (2016). Determinants of father involvement with young children: evidence from the early childhood longitudinal study-birth cohort. Journal of Family Psychology, 30(1), 135 https://doi.org/10.1037/fam0000156.

Phares, V., Fields, S., \& Kamboukos, D. (2009). Fathers' and mothers' involvement with their adolescents. Journal of child and family studies, 18(1), 1-9. https://doi.org/10.1007/s10826-008-9200-7.

Reimers, A. K., Jekauc, D., Mess, F., Mewes, N., \& Woll, A. (2012). Validity and reliability of a self-report instrument to assess social support and physical environmental correlates of physical activity in adolescents. BMC public health, 12(1), 1-10. https://doi.org/ 10.1186/1471-2458-12-705.

Said-Foqahaa, N., \& Maziad, M. (2011). Arab women: Duality of deprivation in decision-making under patriarchal authority. Hawwa, 9(1-2), 234-272. https://doi.org/10.1163/156920811x578539.

Salem, R., \& Yount, K. M. (2019). Structural accommodations of patriarchy: women and workplace gender segregation in Qatar. Gender, Work \& Organization, 26(4), 501-519. https://doi.org/ 10.1111/gwao.12361.

Saraff, A., \& Srivastava, H. C. (2010). Pattern and determinants of paternal involvement in childcare: an empirical investigation in a metropolis of India. Population Research and Policy Review, 29 (2), 249-273. https://doi.org/10.1007/s11113-009-9139-4.

Shafaie, S., Mayers, G., Al-Maadadi, F. Y., Coughlin, C., \& Wooldridge, D. G. (2014). Females' perception of the role of fathers in caring for children. International Journal of Education and Social Science, 1(3), 20-31. https://web.archive.org/web/ 20180410145410id_/http://www.ijessnet.com/wp-content/uploa ds/2014/10/3.pdf.

Stocker, J. N. M., \& Ali, K. G. (2014). Parent-child relationships in the United Arab Emirates. International Journal of Developmental and Educational Psychology, 3(1), 363-374. https://www.reda lyc.org/pdf/3498/349851785036.pdf.

Selwaness, I., \& Krafft, C. (2021). The dynamics of family formation and women's work: what facilitates and hinders female employment in the Middle East and North Africa? Population Research and Policy Review, 40(3), 533-587. https://doi.org/10. 1007/s11113-020-09596-6.

Shockley, K. M., Shen, W., DeNunzio, M. M., Arvan, M. L., \& Knudsen, E. A. (2017). Disentangling the relationship between gender and work-family conflict: an integration of theoretical perspectives using meta-analytic methods. Journal of Applied Psychology, 102(12), 1601 https://doi.org/10.1037/apl0000246.

Tanaka, S., \& Waldfogel, J. (2007). Effects of parental leave and work hours on fathers' involvement with their babies: evidence from the millennium cohort study. Community, Work and Family, 10 (4), 409-426. https://doi.org/10.1080/13668800701575069.

Vygotsky, L. S. (1980). Mind in Society: The Development of Higher Psychological Processes. Harvard University Press. http://ouleft. org/wp-content/uploads/Vygotsky-Mind-in-Society.pdf.

Verhoeven, M., Bögels, S., \& van der Bruggen, C. (2011). Unique roles of mothering and fathering in child anxiety; moderation by child's age and gender. Journal of Child and Family Studies, 21 (2), 331-343. https://doi.org/10.1007/s10826-011-9483-y. 